\title{
\begin{tabular}{l|l|l} 
& Jurnal Kependidikan Dasar & Volume :4 \\
Nomor $: 1$ \\
Islam Berbasis Sains & Tahun $: 2019$ \\
\hline
\end{tabular}
}

\section{Pengelolaan Majlis Taklim Dan Pengajian Umum}

\author{
Muh. Khoirul Rifa'i \\ UIN Sunan Ampel Surabaya \\ rifai@uinsby.ac.id
}

\begin{abstract}
Majlis taklim is a recitation association, so the motive is to seek religious knowledge and get merit from Allah, so the participants are growing rapidly in various regions. In order to be effective and efficient, the majlis taklim needs to be managed properly by arranging the curriculum to the guidance of rolling ustadz who provide the material. General recitation is the study of religious knowledge which is displayed to the public and all audiences. Public recitations get a variety of challenges and to face these challenges, general recitation needs strategic steps.
\end{abstract}

Keywords: Management, Taklim Majlis, General Studies

\begin{abstract}
Abstrak
Majlis taklim merupakan perkumpulan pengajian, sehingga motifnya adalah mencari ilmu agama dan mendapatkan pahala dari Allah, sehingga pesertanya semakin berkembang pesat di berbagai daerah. Supaya berlangsung efektif dan efisien, maka majlis taklim perlu dikelola dengan baik dengan ditata kurikulumnya sampai pada pembinaan juga rolling ustadz yang memberikan materi. Pengajian umum adalah pengajian ilmu agama yang sifatnya ditampilkan untuk umum dan semua khalayak. Pengajian umum mendapatkan berbagai tantangan dan untuk menghadapi tantangan tersebut maka pengajian umum perlu langkah-langkah strategis.
\end{abstract}

Kata Kunci: Pengelolaan, Majlis Taklim, Pengajian Umum

\section{Pendahuluan}

Dalam agama Islam segala sesuatu tidak boleh dikerjakan secara asal-asalan. Semuanya harus teratur dan dikerjakan secara tertib. Terlebih lagi prosesprosesnya, semuanya harus terencana dengan baik dan teratur. Arah pekerjaan yang jelas juga landasan yang jelas dan cara- caranya yang transparan akan menjadikan perbuatan yang dikerjakan mendapatkan ridho dan hidayah dari Allah. Sebenarnya manajemen dalam arti mengatur agar sesuatu itu teratur dan berjalan secara efektif dan efisien merupakan sesuatu yang disukai Allah, dan merupakan hal yang dianjurkan dalam syariat Islam, bahkan 
boleh dikatakan hal itu termasuk kategori sunnah. Karena Nabi Muhammad SAW tidak pernah melakukan sesuatu secara asal-asalan apalagi tanpa rencana. Memang manusia hanya bisa merencanakan, tetapi tanpa rencana maka tatanan segala sesuatu akan menjadi tidak karuan.

Bahkan majlis taklim dan pengajian umum juga perlu untuk dikelola dengan baik supaya mampu menjadi lembaga pendidikan Islam nonformal yang efektif. Majlis taklim dan pengajian sudah sangat marak di Indonesia, bahkan majlis taklim hampir setiap minggu dilaksanakan sebagai bentuk siraman rohani kepada masyarakat. Sedangkan pengajian umum biasanya diadakan ketika ada even-even tertentu misalnya peringatan hari besar agama Islam.

Namun, kebanyakan yang terjadi dua organisasi tersebut tidak dikelola dengan baik alias tidak mempunyai manajemen yang baik. Akibatnya majlis taklim menjadi organisasi yang membosankan karena materi yang dikaji juga membosankan. Ustadz yang memberikan materi tidak mampu menyajikan materi secara lebih up date lagi. Hal sama juga terjadi dalam pengajian umum. Pengajian umum sekarang nampak menurun peminatnya dibandingkan pengajian umum pada masa orde baru. Maka dari itu, perlu pengelolaan yang tepat pada majlis taklim dan pengajian umum supaya menjadi organisasi yang berperan serta dalam mencerdaskan masyarakat dalam pendidikan Islam

\section{Konsep Dasar Majlis Taklim}

Ada beberapa gejala menarik dalam perkembangan kehidupan keagamaan di masyarakat belakangan ini. Pengamatan secara umum memperlihatkan, bahwa setidak-tidaknya dua dasawarsa terakhir kehidupan keagamaan di masyarakat terlihat begitu semarak. Dan bila di lihat fenomena tersebut tersebut merupakan sebuah konsekuensi dari perubahanperubahan yang terjadi dalam kehidupan sosial, budaya politik ekonomi dalam masyarakat.

Salah satu bentuk perkembangan kehidupan keagamaan khususnya dalam pembinaan umat adalah "lembaga" Majelis Taklim. Majelis taklim merupakan salah satu lembaga pendidikan non formal yang mempunyai fungsi dan peranan dalam pembinaan umat, sebagai taman rekreasi rohaniah dan ajang dialog serta silaturrahmi antara ulama, umara dengan umat.

Majelis taklim merupakan salah satu model pendidikan non formal yang diharapkan dapat berkembang bersama dengan lembaga pendidikan lainnya. Model pembinaan di majelis taklim diharapkan dapat menawarkan sebuah solusi dari problematika yang dihadapi umat di antaranya berupa tantangan akibat kemajuan teknologi, masalah hubungan sosial. Masalah pembinaan keluarga dan masalah pendidikan anak. ${ }^{1}$

Posisi strategis majelis taklim yang berdiri sejajar dengan lembaga pendidikan lainnya seperti sekolah, madrasah atau pesantren menempatkan dirinya mengakar di masyarakat. Sehingga peranannya sebagai sarana pembinaan umat sangatlah penting. Dapat diprediksikan jika seandainya umat Islam hanya terikat pada pendidikan formal yang terbatas pada lembaga sekolah atau madrasah saja, maka banyak celah yang tidak tertutupi. Untuk itu majelis taklim berperan sebagai pembinaan umat alternatif yang ada di masyarakat.

1 Zakiah Daradjat, Metodik Khusus Pengajaran Agama Islam (Jakarta: Bulan Bintang, 1980), 9-11. 
Menurut akar katanya, istilah majelis taklim tersusun dari gabungan dua kata : majelis yang berarti (tempat) dan taklim yang berarti (pengajaran) yang berarti tempat pengajaran atau pengajian bagi orang-orang yang ingin mendalami ajaranajaran Islam sebagai sarana dakwah dan pengajaran agama.

Majelis taklim adalah salah satu lembaga pendidikan diniyah non formal yang bertujuan meningkatkan keimanan dan ketakwaan kepada Allah SWT dan akhlak mulia bagi jamaahnya, serta mewujudkan rahmat bagi alam semesta. ${ }^{2}$ Amri Marzali menyatakan, "Majlis taklim adalah suatu perhimpunan orang banyak untuk mendengarkan ceramah atau kuliah agama Islam dari seorang muallim." ${ }^{3}$ Sedangkan menurut Mujamil, majlis taklim merupakan perkumpulan pengajian, sehingga motifnya adalah mencari ilmu agama dan mendapatkan pahala dari Allah, sehingga pesertanya semakin berkembang pesat di berbagai daerah, khususnya kalangan ibu-ibu rumah tangga yang merasakan haus siraman rohani. ${ }^{4}$

Dalam prakteknya, majelis taklim merupakan tempat pangajaran atau pendidikan agama Islam yang paling fleksibel dan tidak terikat oleh waktu. Majelis taklim bersifat terbuka terhadap segala usia, lapisan atau strata sosial, dan jenis kelamin. Waktu penyelenggaraannya pun tidak terikat, bisa pagi, siang, sore,

\footnotetext{
2 Muhayat, Manajemen dan Silabus Majelis Taklim (Jakarta: Pusat Pengkajian dan Pengembangan Islam Jakarta, 2012), 12.

3 Amri Marzali, Pemberdayaan Majlis Taklim Melalui Pendekatan Sosiologi,", dalam Kustini (ed.), Hasil Seminar Peningkatan Peran Serta Masyarakat dalam Pendalaman Ajaran Agama Melalui Majlis Taklim, (Jakarta: Badan Litbang dan Diklat Puslitbang Kehidupan Keagamaan Departemen Agama RI, 2007), 53.

4 Mujamil Qomar, Dimensi Manajemen Pendidikan Islam (Jakarta: Erlangga, 2015), 76.
}

atau malam. tempat pengajarannya pun bisa dilakukan di rumah, masjid, mushalla, gedung, aula, halaman, dan sebagainya. Selain itu majelis taklim memiliki dua fungsi sekaligus, yaitu sebagai lembaga dakwah dan lembaga pendidikan non formal. Fleksibilitas majelis taklim inilah yang menjadi kekuatan sehingga mampu bertahan dan merupakan lembaga pendidikan Islam yang paling dekat dengan umat (masyarakat). Majelis taklim juga merupakan wahana interaksi dan komunikasi yang kuat antara masyarakat awam dengan para mualim, dan antara sesama anggota jamaah majelis taklim tanpa dibatasi oleh tempat dan waktu.

Dengan demikian majelis taklim menjadi lembaga pendidikan keagamaan alternatif bagi mereka yang tidak memiliki cukup tenaga, waktu, dan kesempatan menimba ilmu agama melalui jalur pendidikan formal. Inilah yang menjadikan majlis taklim memiliki nilai karakteristik tersendiri bila dibanding lembaga-lembaga keagamaan lainnya.

Melihat peran yang begitu besar dari majelis taklim ini, maka pemerintah menjadikan majelis taklim sebagai sub sistem pendidikan nasional sebagaimana tertuang dalam Undang-undang Republik Indonesia Nomor 20 Tahun 2003 tentang Sistem Pendidikan Nasional pada Pasal 30 tentang pendidikan Keagamaan. ${ }^{5}$

Potensi dan peran strategis majelis taklim hendaknya didukung dengan manajemen yang baik, SDM yang profesional (ahli dalam bidangnya) dan kurikulum yang sistematik dan berkesinambungan. Karena secara realitas banyak sekali ditemukan majelis taklim yang dikelola apa adanya, SDM yang lemah

5 UU RI, “No. 20 Tahun 2003," Tentang Sistem Pendidikan Nasional, 2003. 
serta pola pengajaran dan pembelajaran yang tidak sistematik, akibatnya terjadi ketidakteraturan dan tumpang tindih antara ustadz/ustadzah yang satu dengan lainnya dalam penyampaian materi taklim.

Ketika ditelusuri secara mendalam, pengajian majlis taklim ini ternyata telah berlangsung lama di berbagai belahan wilayah dunia Islam, sehingga bukan lagi fenomena yang baru sama sekali. M. Arifin melaporkan bahwa menurut pengalaman historis islami, sistem majlis taklim telah berlangsung sejak awal penyebaran Islam di benua Arabia, kemudian menyebar ke seluruh penjuru dunia Islam di Asia, Afrika dan khususnya Indonesia sampai saat ini. ${ }^{6}$ Namun Arifin tidak menjelaskan secara detail tentang proses pertumbuhan majlis taklim tersebut di Indonesia. Hanya saja yang tampak di permukaan, majlis taklim itu cepat menyebar di berbagai wilayah tanah air terutama dipelopori majlis taklim yang ada di kota-kota besar. Boleh jadi terdapat majlis taklim di desa yang lebih lama usianya daripada majlis taklim di kota, tetapi lantaran perkembangan majlis taklim di kota-kota besar bergerak ekspansif mengakibatkan kesan bahwa pertumbuhan dan perkembangannya dengan pesat didominasi oleh majlis taklim-majlis taklim yang berada di kota-kota besar terutama majlis taklim yang berada di Jakarta.

Oleh karena itu, pengajian dalam majlis taklim memiliki ciri-ciri khusus yang bisa dibedakan dengan model-model pengajian lainnya. Kustini sebagaimana dikutip Mujamil, mengidentifikasi karakteristik mayoritas majlis taklim yang berkembang di Indonesia ini sebagai berikut:

Tumbuh atas inisiatif masyarakat, melibatkan partisipasi perempuan,

\footnotetext{
6 H. Muzayyin Arifin, Kapita Selekta Pendidikan (Islam dan Umum) (Jakarta: Bumi Aksara, 1991), 119.
}

mengadakan pengajian seminggu sekali, metode penyampaian materi dengan ceramah dan hanya sedikit alokasi waktu untuk diskusi, penceramah bergantiganti, tidak memiliki kurikulum, tidak ada administrasi yang ketat tentang persyaratan untuk menjadi jamaah, kondisi jamaah relatif homogin khususnya dari segi jenis kelamin dan usia. Itulah beberapa karakteristik dari kebanyakan majlis taklim di Indonesia yang dari segi kuantitas terus mengalami perkembangan. ${ }^{7}$

Identifikasi karakteristik ini memberikan pemahaman tentang kondisi majlis taklim, setidaknya ditilik dari segi manajerial masih jauh dari professional. Disamping karakteristik majlis taklim tersebut, ternyata majlis taklim yang tersebar di Indonesia ini memiliki tipologi yang cukup bervariasi khususnya ditinjau dari segi perintis atau pendirinya. M. Syatibi al-Haqiri melaporkan sebagaimana dikutip Mujamil, bahwa dari hasil penelitian terhadap 13 majlis taklim, antara lain menyimpulkan adanya tipologi atau model yang berlainan, yaitu: ${ }^{8}$

1. Majlis taklim yang digerakkan oleh seorang tokoh agama yang berpengaruh di daerahnya;

2. Majlis taklim yang dibangun atas dasar kegiatan wirausaha dalam rangka menopang pembinaan pengajian pada kelompok remaja;

3. Majlis taklim yang dibangun atas kesepakatan beberapa pimpinan majlis taklim;

4. Majlis taklim yang didirikan atas prakarsa pengusaha/perorangan atas dasar keinginan untuk mempelajari agama dan meningkatkan wawasan pengetahuan keagamaan;

\footnotetext{
Qomar, Dimensi Manajemen Pendidikan Islam, 79. 8 Qomar, 80.
} 
5. Majlis taklim yang didirikan dalam rangka memenuhi kebutuhan masyarakat;

6. Majlis taklim yang diprakarsai oleh pengurus takmir masjid atau mushalla yang secara rutin melakukan pengajian mingguan dan bulanan.

Bahkan, majelis taklim kini telah hadir dengan beragam bentuk dan ciri-ciri yang khas sesuai dengan kelompok dan latar belakang jamaahnya, yang dapat dibedakan antara lain: ${ }^{9}$

1. Dilihat dari jamaahnya

a. MT Kaum Ibu/Muslimah/Perempuan

b. MT Kaum Bapak/Laki-laki

c. MT Kaum Remaja/Pemuda

d. MT Campuran Ibu-ibu dan Bapakbapak

e. MT Selebritis

2. Dilihat dari organisasinya
a. MT Biasa (tanpa legalitas formal)
b. MT Berbadan hukum Yayasan
c. MT Berbentuk Ormas
d. MT di bawah Ormas dan Orsospol
e. MT di bawah lembaga pemerintah.

3. Dilihat dari tempatnya
a. MT Masjid dan Mushola
b. MT Perkantoran dan Sekolah
c. MT Perhotelan
d. MT Pabrik dan Industri
e. MT Komplek Perumahan
f. MT Perkampungan

Tipologi ini masih bisa digerakkan dan dikembangkan lagi menjadi lebih kompleks manakala ditinjaudariperspektifkomponen lainnya. Enam macam tipe tersebut baru ditinjau dari segi perintis atau pendirinya. Distingsi majlis taklim itu dapat ditinjau dari segi peserta pengajiannya, penekanan materi pengajian yang disampaikan, dan tempat pelaksanaannya. Bila majlis taklim

9 Manajemen dan Silabus Majelis Taklim, 26-27. ditinjau dari segi pesertanya, masih bisa dibedakan dari sisi usia peserta maupun profesinya. Dari sisi usia peserta, terdapat majlis taklim bagi anak-anak, majlis taklim bagi remaja, majlis taklim bagi orang dewasa, majlis taklim bagi ibu-ibu dan majlis taklim bagi bapak-bapak. Sedangkan dari sisi profesi peserta, terdapat majlis taklim bagi kiai, majlis taklim bagi sarjana, majlis taklim bagi ustadz, majlis taklim bagi artis, majlis taklim bagi kepala sekolah, majlis taklim bagi guru, majlis taklim bagi karyawan, majlis taklim bagi pedagang, majlis taklim bagi pengusaha, dan lainlainnya. Dari segi materi pengajian yang disampaikan terdapat majlis taklim khusus membahas akidah (teologi), majlis taklim khusus membahas al-Qur'an, majlis taklim khusus membahas hadits, majlis taklim khusus membahas fiqh, majlis taklim khusus membahas tasawuf, dan majlis taklim khusus membahas masalah-masalah sosial. Adapun ditinjau dari segi tempat pelaksanaannya, terdapat majlis taklim yang dilaksanakan di pesantren, masjid, mushalla, gedung khusus, perkantoran, dan rumah penduduk.

\section{Pengelolaan Majlis Taklim}

Munir melaporkan adanya beberapa hambatan dan tantangan yang dihadapi majlis taklim, baik secara internal maupun secara eksternal, dalam mewujudkan akselerasi dan eskalasi pemberdayaan umat, antara lain:

1. Keberadaan majlis taklim yang demikian besar tidak didukung oleh manajemen yang baik dan professional,

2. Kurang pemerataan tenaga guru,

3. Masih rendahnya kualitas guru majlis taklim,

4. Lemahnya sistem pembelajaran pada majlis taklim yang tidak sesuai 
dengan kebutuhan mad'u (orang yang didakwahi),

5. Mayoritas jamaah majlis taklim berpendidikan rendah,

6. Tidak memiliki sumber dana yang jelas/ tetap,

7. Kurangnya sistem yang kondusif, tidak adanya reward dan punishment,

8. Metode pembelajaran yang monoton menyebabkan majlis taklim akan ditinggalkan jamaahnya,

9. Lemahnya manajer/pengelola majlis taklim akan menyebabkan hilangnya kepercayaan jamaah kepada majlis taklim,

10.Terjadinya konflik internal antara pengurus/asatidz/asatidzah,

11.Masih banyak pengurus majlis taklim yang militansi dan ruh al-jihad-nya lemah sehingga menyebabkan rendahnya rasa kepemilikan terhadap organisasi,

12.Kurang adanya pemetaan yang jelas terhadap objek dakwah sehingga seringkali berakibat perebutan satu majlis taklim oleh asatidz,

13.Lembaga-lembaga dakwah terlihat berjalan sendiri-sendiri sehingga tidak terjadi sinergitas, dan

14.Belum tersedianya peta dakwah. ${ }^{10}$

Supaya majlis taklim dapat berjalan secara efektif dan efisien, maka perlu ada prinsip pengelolaan majlis taklim. Berikut ini adalah prinsip pengelolaan majlis taklim sebagai berikut: ${ }^{11}$

1. Bahwa inti majelis taklim adalah penanaman nilai-nilai agama, oleh karenanya dapat digunakan pendekatan psikologis dalam memahami potensi yang dimiliki peserta/jamaah, yaitu melalui pende-katan potensi kognitif

\footnotetext{
10 Qomar, Dimensi Manajemen Pendidikan Islam, 82-83.

11 Manajemen dan Silabus Majelis Taklim, 25-26.
}

(daya nalar), potensi efektif (daya merasa), potensi psikomotorik (daya melaksanakan) ajaran agama.

2. Para pengelola majelis taklim hendaknya memahami tentang: Pengertian, sejarah, tujuan, kedudukan, persyaratan, unsurunsur, jenis sarana prasarana, waktu penyelenggaraan, peserta/jamaah, kegiatan kemasya-rakatan, penilaian dan khitah majelis taklim.

3. Setiap majelis taklim hendaknya memiliki pedoman pelaksanaan pengajaran atau KBM yang terdiri dari : Kurikulum, Materi, Metode, Persiapan pengajaran dan penilaian.

4. Setiap majelis taklim hendaknya memiliki pedoman penyelenggaraan administrasi yang baik, dengan melaksanakan dasar dan asas-asas serta prinsip organisasi yang lebih sederhana, yaitu : Planing, Organiting, Actuiting dan Controling (POAC).

Selanjutnya, dapat dilakukan pemetaan strategi pengelolaan pengajian majlis taklim secara lebih mendetail pada masingmasing komponen, antara lain: ${ }^{12}$

1. Pengelolaan sarana-prasarana Sarana prasarana majlis taklim perlu disiapkan secara khusus agar kegiatan pengajian yang dilaksanakan berjalan dengan tertib dan lancar. Sarana yang harus diatur ini meliputi gedung, meja, kursi, tikar, karpet, media pembelajaran (OHP, tape recorder, laptop, LCD dan lain-lain), sound system, salon dan sebagainya. Sedangkan prasarana yang perlu diperhatikan dan dikelola ini merupakan fasilitas yang secara tidak langsung menunjang proses pembelajaran seperti jalan menuju gedung tempat pengajian, tempat parkir

12 Qomar, Dimensi Manajemen Pendidikan Islam, 84-87. 
kendaraan jamaah, halaman gedung pengajian dan sebagainya.

2. Pengelolaan keuangan

Posisi keuangan bagi organisasi apa pun termasuk pengajian majlis taklim berfungsi bagai bensin bagi kendaraan. Tanpa adanya uang, majlis taklim terasa sulit dipertahankan, sebab uang tersebut untuk membiayai seluruh kebutuhan pelaksanaan pengajian majlis taklim. Maka keuangan ini seharusnya mendapat perhatian sangat serius bagi pengurus majlis taklim.Mereka segera menyiapkan langkah-langkah dan strategi-strategi yang efektif dalam mengumpulkan uang. Hal ini bisa dilakukan melalui akumulasi berbagai cara, antara lain : (a) penarikan iuran pada masingmasing anggota, (b) menggali donatur yang siap menyuplai pendanaan secara teratur, (c) mendirikan koperasi yang melayani jamaah sendiri maupun orang di luar jamaah, (d) mendirikan usaha-usaha produktif yang efektif menghasilkan keuntungan finansial, (e) menanam saham pada perusahaan tertentu sebagai bentuk usaha bersama, dan (f) berinvestasi pada bidang atau barang yang nilai ekonomisnya cepat berkembang.

3. Pengelolaan Personalia

Pengelolaan personalia ini dimaksudkan mengelola pengurus dan ustadz majlis taklim, meskipun hanya termasuk pendidikan agama Islam non formal. Majlis taklim ini harus memiliki pengurus formal yang bertugas mengendalikan jalannya proses pelaksanaan pengajian secara rutin. Maka majlis taklim harus memiliki struktur oraganisasi yang jelas orang-orangnya, kedudukannya, dan pekerjaannya (tanggungjawabnya). Sedangkan ustadz sebagai pengasuh majlis taklim juga harus dikelola dengan baik.Ustadz ini secara garis besar dapat dibagi dua, yaitu ustadz yang relatif permanen dan ustadz yang insidentil. Ustadz yang permanen merupakan ustadz yang secara rutin mengasuh pengajian majlis taklim itu. Mereka ditetapkan sebagai pengasuh tetap bagi majlis taklim, atau semacam dikontrak dalam batas waktu tertentu berdasarkan kesepakatan kedua belah pihak. Adapun ustadz yang insidentil tersebut merupakan ustadz yang dihadirkan untuk mengisi pengajian majlis taklim sebagai selingan pengasuh pengajian atau dalam rangka peringatan hari-hari besar Islam. Disini juga penting sekali memperhatikan dan meningkatkan kualitasustadz/ustadzahyang mengasuh majlis taklim dengan cara ustadz sendiri yang meningkatkan pembekalan dirinya, menempuh pendidikan berikutnya, atau berusaha menjalin interaksi dengan orang-orang yang sangat kompeten dalam menguasai khazanah Islam. Cara lain yang bisa ditempuh, tetapi cara ini mungkin belum pernah ditempuh, yaitu organisasi para ustadz/ustadzah maupun forum komunikasi majlis taklim memondokkan ustadz/ustadzah ke ma'had aly atau menguliahkan ustadz/ ustadzah ke tingkat yang lebih tinggi daripada tingkat pendidikan yang telah mereka dialami.

4. Pengelolaan Jamaah

Problem jamaah majlis taklim yang perlu dikelola adalah menyangkut usia jamaah, jenis kelamin jamaah, dan frekuensi kehadiran. Majlis taklim ada yang eksklusif, maksudnya majlis taklim diperuntukkan kelompok usia tertentu seperti majlis taklim untuk anak-anak, maka konsekuensinya orang dewasa 
tidak boleh mengikuti. Namun ada juga majlis taklim yang inklusif, artinya majlis taklim yang diperuntukkan masyarakat umum, maka siapa pun boleh mengikutinya; dari segi kelamin jamaah terdapat majlis taklim yang khusus diikuti ibu-ibu, maka bapakbapak tidak boleh mengikutinya, atau sebaliknya, majlis taklim yang dikhususkan bagi bapak-bapak maka ibu-ibu tidak boleh mengikutinya. Akan tetapi ada majlis taklim yang diselenggarakan secara umum untuk laki-laki maupun perempuan, sehingga siapa pun boleh menjadi jamaah dan mengikutinya; kemudian menyangkut frekuensi kehadiran, pengurus bersama jamaah perlu membangun komitmen untuk mengikuti pengajian majlis taklim secara aktif, disiplin dan rutin kecuali dalam kondisi darurat.

5. Pengelolaan Kurikulum

Kurikulum bisa diartikan sebagai rencana atau rancangan pengajaran (ta'lim) yang dibuat dan dilaksanakan untuk mencapai tujuan ta'lim yang telah ditetapkan. Dalam hal ini, kurikulum berisi susunan materi ta'lim yang dijadikan pedoman atau panduan seorang mualim dalam menyampaikan materi. Materi ta'lim ini disusun berdasarkan urutan atau tahapan dari satu pertemuan ke pertemuan berikutnya, sehingga memudahkan ustadz dalam mengajar dan memudahkan jamaah untuk memahami materi ta'limnya. Kurikulum majlis taklim ini harus jelas materinya, jelas arahnya, terbuka dan partisipatif. Ustadz yang permanen itu harus segera menyusun kurikulum pengajian bersama pengurus dan jamaah majlis taklim. Ustadz tersebut bisa juga minta pandangan dan pertimbangan dari pengurus majlis taklim lainnya yang telah mapan kurikulumnya. Mekanismenya adalah sebagai berikut: (a) ustadz merancang materi pengajian yang akan disampaikan dalam waktu tertentu misalnya selama satu tahun, (b) ustadz mendiskusikan rancangan materi pengajiannya dengan pengurus dan jamaah majlis taklim, (c) ustadz menggali usulan-usulan materi pengajian dari pengurus dan jamaah majlis taklim, (d) ustadz bersama pengurus dan jamaah mengidentifikasi masalah-masalah sosial yang layak dibahas dalam pengajian majlis taklim, dan (e) ustadz menetapkan materi pengajian yang akan dibahas dalam batas waktu tertentu sebagai kesepakatan bersama pengurus dan jamaah majlis taklim.

6. Pengelolaan Pembelajaran

Model pembelajaran yang hanya menggunakan metode ceramah dalam pengajian majlis taklim sehingga jamaah hanya mendengar dan melihat aktivitas ustadz/ustadzah, perlu dipikirkan dan disempurnakan dengan menggunakan berbagai metode secara bergantian agar menarik karena perlu dikombinasikan dengan metodemetode lainnya. Ada beberapa metode lainnya yang bisa dimanfaatkan dalam menyampaikan pengajian majlis taklim, yaitu metode tanya jawab, diskusi/seminar, demonstrasi, latihan siap (drill), pemecahan masalah (problem solving) dan sistem regu (team teaching). Metode ceramah digunakan untuk menyampaikan materi pembahasan yang membutuhkan banyak penjelasan secara lesan; metode tanya jawab diterapkan ketika dibutuhkan penajaman penguasaan materi pembahasan dan pengetahuan 
tentang keinginan-keinginan jamaah; metode diskusi/seminar digunakan pada saat menyampaikan materi pembahasan yang membutuhkan pemikiran dan penalaran yang kritis, metode demonstrasi digunakan ketika dibutuhkan penjelasan-penjelasan yang melibatkan peragaan seperti peragaan cara-cara berwudlu, cara-cara tayamun, cara-cara shalat dan cara=cara haji berikut umrahnya; metode latihan siap (drill) digunakan menyampaikan materi pengajian ketika dibutuhkan penguasaan ketrampilan seperti latihan membaca al-Qur'an, latihan membaca sanad dan matan hadits, latihan membaca kitab jenggot, dan latihan membaca baitbait syiir Arab; metode pemecahan masalah (problem solving) digunakan ketika menyampaikan pembahasan yang bersifat problematik sehingga menuntut pencarian solusi untuk memecahkannya; sedangkan metode sistem regu (team teaching) digunakan ketika menyampaikan pembahasan yang bersifat dialogis maupun komparatif sehingga perlu menghadirkan dua orang ustadz di depan jamaah majlis taklim untuk menyampaikan pengajian secara bergantian (bersahut-sahutan). Penerapan metode ini juga bisa dilakukan dengan bergantian waktu penyampaikan seperti masing-masing ustadz hanya menyampaikan materi di hadapan jamaah dua minggu sekali.

\section{Konsep Dasar Pengajian Umum}

Di kalangan masyarakat Muslim Indonesia dikenal pengajian umum. Pengajian ini memiliki sebutan yang bermacam-macam sesuai hajat yang terkandung dalam pengajian itu sehingga terdapat pengajian Muharram, Maulid Nabi,
Isra' Mi'raj, Imtihan akhir al-sannah, Nuzul al-Qur'an, Halal bihalal, Manakib Kubra, Istighasah Kubra, dan Haul Akbar. Pengajian Muharram dalam rangka menyambut tahun baru hijriah; pengajian Maulid Nabi merupakan pengajian yang memperingati kelahiran Nabi Muhammad Saw dengan menjabarkan perilakunya, akhlaknya dan perjuangannya yang seharusnya diteladani umat Islam; pengajian Isra' Mi'raj merupakan pengajian yang dilaksanakan untuk memperingati peristiwa perjalanan istimewa yang ditempuh Nabi Muhammad Saw dari masjid al-Haram hingga masjid al-Aqsha kemudian diteruskan ke Sidrat al-Muntaha dalam rangka menerima titah/kewajiban ibadah shalat; pengajian Imtihanakhir al-sannah merupakan pengajian dalam rangka mengakhiri tahun ajaran dalam pembelajaran di pesantren maupun di lembaga pendidikan Islam lainnya; pengajian Nuzul al-Qur'an merupakan pengajian yang dilaksanakan untuk memperingati peristiwa turunnya al-Qur'an di masa kehidupan Nabi Muhammad Saw; pengajian Halal bihalal merupakan pengajian yang dilaksanakan terkait dengan hari Raya Fitri untuk memperkokoh silaturrahmi khususnya sesama umat Islam; pengajian ManakibKubra merupakan pengajian yang dilaksanakan dengan mengurai sejarah kehidupan ulama besar dalam Islam untuk diambil hikmah dan teladannya seperti Manakib Syaikh Abd al-Qadir al-Jilani. Pengajian ini disebut pengajian Manakib Kubra karena pelaksanaan pengajian itu diikuti jamaah dalam skala yang besar; pengajian Istighasah Kubramerupakan pengajian yang menekankan pada dzikir bersama meminta pertolongan kepada Allah lalu dilanjutkan ceramah yang diikuti jamaah dalam skala yang besar; sedangkan 
pengajian Haul Akbar merupakan pengajian yang dilaksanakan setahun sekali terkait dengan peringatan hari wafat ulama besar dalam Islam yang diikuti jamaah dalam skala besar seperti pengajian Haul Akbar Sunan Bonang yang dilaksanakan di masjid Jami' Tuban.

Waktu pelaksanaan pengajian tersebut secara garis besar terbagi menjadi dua, yaitu terikat waktu tertentu dan bebas memilih waktu. Pelaksanaan pengajian yang terikat oleh waktu adalah pengajian Muharram, Maulid Nabi, Isra' Mi'raj, Imtihan akhir al-sannah, Nuzul al-Qur'an, Halal bihalal, dan Haul Akbar. Sedangkan pelaksanaan pengajian umum yang bebas memilih waktu adalah pengajian Manakib Kubra dan Istighasah Kubra.Pengajian Muharram sesuai dengan namanya dilaksanakan pada setiap bulan Muharram, pengajian Maulid Nabi dilaksanakan setiap bulan Rabi' alAwwal, pengajian Isra' mi'raj dilaksanakan setiap bulan Rajab, pengajian Imtihanakhir al-sannah dilaksanakan setiap bulan Sya'ban, pengajian Nuzul al-Qur'anbiasanya dilaksanakan pada 17 Ramadhan, pengajian Halal bihalaldilaksanakan pada awal bulan Syawwal mengiringi hari Raya Fitri, sedangkan pengajian Haul Akbardilaksanakan sesuai dengan tanggal dan bulan kematian seseorang tokoh atau ulama besar yang sedang diperingati. Adapun pelaksanaan pengajian Manakib Kubra tidak terlalu terikat waktu. Apalagi pelaksanaan pengajian Istighasah Kubrasama sekali tidak terikat waktu. Pengajian ini justru terkait dengan kepentingan-kepentingan yang besar, misalnya kondisi kepemimpinan Negara dalam keadaan terancam maka umat Islam perlu bermunajat memohon pertolongan kepada Allah melalui kegiatan istighasah.
Pengajian umum tersebut bersifat bebas dan terbuka. Jamaah yang mengikuti pengajian itu tidak pernah dibatasi oleh usia, jenis kelamin, jenis profesi, jenis kesukuan, status sosial, dan lain sebagainya. Maka pengajian umum itu diikuti anak-anak, kalangan remaja, orang-orang dewasa, orang-orangtua, kaum laki-laki, kaum perempuan, petani, pedagang, nelayan, karyawan, pegawai, artis, aktivis lembaga swadaya masyarakat, wartawan, guru, dosen, polisi, tentara, pengusaha, pejabat, orang Jawa, orang Madura, orang Sunda, orang Bogis, orang fakir, orang miskin, orang kaya, konglomerat dan lain-lain. Intinya pengajian umum itu menampung semua lapisan masyarakat Muslim yang ingin mengikuti siraman rohani tersebut tanpa batas apapun. Bahkan seandainya terdapat orang-orang non Muslim ingin mengikuti dan mendengarkan pengajian itu bersama-sama orang-orang Islam juga sangat mungkin terjadi dan tidak akan diusir oleh panitia.

Jamaah pengajian umum itu bisa hadir di lokasi pengajian melalui berbagai saluran informasi baik karena diundang secara khusus, mendengar pengumuman di masjid-masjid menjelang khutbah jum'at, mendengar siaran keliling memakai mobil dan speaker, mendengar siaran radio, membaca berita di surat kabar, dan mendengar kabar dari orang lain termasuk teman maupun tetangganya. Oleh karena itu, pengajian itu memungkinkan mampu menghadirkan jamaah dalam jumlah yang sangat besar hingga membludak dan meluber ke mana-mana, sehingga harus disiapkan tempat atau lokasi yang mencukupi dan mampu menampung jamaah seluruhnya sebagai langkah antisipasi.Pengalaman menunjukkan bahwa pengajian umum biasanya dihadiri 
jamaah dalam jumlah yang besar. Apabila tempat pengajian itu sempit maka akan mengganggu proses pengajian itu sendiri dan panitia dibikin repot mengatur jamaah yang hadir tersebut.

\section{Pengelolaan Pengajian Umum}

Dalam pengajian umum tersebut, ada beberapa pihakyangseharusnyamelakukan pengelolaan sesuai dengan kapasitasnya masing-masing. Ada organisasi sosial keagamaan seperti NU, Muhammadiyah dan Persis; panitia pengajian; dan pembicara/muballigh. Mereka harus memanage pengajian umum itu menjadi kegiatan yang potensial dan fungsional bagi umat Islam melalui terobosan-terobosan yang kreatif dan produktif sebagai berikut: pertama, bagi pengurus organisasi sosial keagamaan perlu memanfaatkan peluang pengajian menjadi rencana jangka panjang yang manfaatnya lebih besar lagi. Misalnya NU sebagai organisasi sosial keagamaan yang memiliki massa paling besar di Indonesia ini dan menaungi masyarakat Muslim khususnya di pedesaan yang gemar melaksanakan pengajian umum itu. Pengurus NU sebaiknya tetap mendorong anggotanya untuk melaksanakan pengajian dan penarikan urunan dalam jumlah yang memadai pada masing-masing desa.Hasil urunan itu sebagian untuk biaya pengajian dan sebagian disisakan.Sisa pembiayaan pengajian pada masing-masing desa sekabupaten itu misalnya diorganisir dan dikoordinir menjadi satu.Kalau dalam satu tahun masing-masing desa mengadakan empat kali pengajian saja seperti pengajian Maulid Nabi, Isra' Mi'raj, Nuzul al-Qur'an dan Halal bihalal, maka sisanya bisa terkumpul besar sekali. Kumpulan sisa dana ini bisa digunakan untuk membeli tanah dan/atau mendirikan poliklinik di wilayah kecamatan secara bergiliran. Jika satu tahun NU bisa mendirikan satu poliklinik dari dana pengajian itu, maka dalam sepuluh tahun akan berdiri 10 poliklinik yang tersebar di 10 kecamatan.

Dengan pendirian dan pembukaan poliklinik ini terdapat nilai-nilai ekonomis, sosial, dakwah dan pendidikan. Nilainilai ekonomis berupa pendapatan dari pelayanan poliklinik itu dan pemberian pekerjaan bagi tenaga medis maupun non medis yang menghasilkan uang dari pengguna jasa poliklinik itu; nilai-nilai sosialnya berupa rekruitmen tenaga kerja baru sehingga dapat mengurangi pengangguran di masyarakat dan pemberian keringanan bagi pasien-pasien yang ekonominya kurang mampu; nilainilai dakwahnya dapat diwujudkan melalui pesan-pesan islami yang disosialisasikan kepada para pasien baik secara lesan maupun tulisan; sedangkan nilai-nilai pendidikannya dapat diwujudkan melalui contoh kehidupan riil yang diberlakukan di dalam poliklinik itu baik praktek kedisiplinan, pelayanan, kebersihan, keamanan maupun kenyamanan dalam area poliklinik tersebut.

Untuk merealisasikan rencana strategis ini, pengurus NU tersebut perlu melakukan serangkaian langkah sebagai berikut: (1)mendesain pemberdayaan dan pengembangan dana pengajian untuk kepentingan yang strategis, produktif dan berjangka panjang; (2)mengidentifikasi dan menetapkan pembangunan strategis, produktif dan berjangka panjang termasuk pendirian poliklinik; (3)melakukan sosialisasi terhadap warga NU yang melaksanakan pengajian itu secara intensif; (4)membangun kepercayaan warga NU tentang pembangunan strategis, produktif dan berjangka panjang 
tersebut;(5)meyakinkan warga NU tentang multimanfaat (multiguna) dari pembangunan tersebut untuk kepentingan umat Islam, bukan untuk kepentingan pribadi pengurus NU; (6)menetapkan dan memantapkan mekanisme pengumpulan dana sisa dari pengajian umum; dan (7) menunjukkan transparansi penggunaan sisa dana pengajian umum itu benar-benar untuk pembangunan yang berorientasi pada kesejahteraan umat Islam.

Kedua, bagi panitia pengajian perlu mereformulasi model penyelenggaraan pengajian umum secara efektif dan efisien. Untuk kepentingan ini, mereka dapat melakukan tindakan sebagai berikut: (1)meniadakan kebutuhan yang kurang penting bagi substansi pelaksanaan pengajian umum seperti pemasangan umbul-umbul; (2)menyeleksi kebutuhankebutuhan pengajian umum secara ketat ; (3)memprioritaskan pemenuhan kebutuhan-kebutuhan pokok (primer); (4) menekan atau meminimalisir pengeluaran dana untuk pemenuhan kebutuhan sekunder dan apalagi kebutuhan tersier bagi pengajian umum; (5)mentargetkan adanya sisa dana pengajian umum dan bahkan berusaha memperbanyak sisa dana pengajian tersebut; (6)memilih tempat yang tepat untuk pelaksanaan pengajian umum dengan mempertimbangkan berbagai kondisi; (7) memproteksi tempat pelaksanaan pengajian umum dari gangguan-gangguan keamanan dan kenyamanan; (8) menggunakan alatspeaker yang paling bagus pantulan suaranya; (9) memfasilitasi timbulnya konsentrasi jamaah dalam mengikuti pengajian yang disampaikan muballigh; (10) membendung tindakan-tindakan panitia yang mengganggu konsentrasi muballigh dan jamaah di tengah-tengah pelaksanaan pengajian umum seperti pembagian kue dan minuman pada saat muballigh sedang menyampaikan pengajian; (11) menjaga jamaah agar mereka tetap mengikuti pengajian hingga selesai yang ditutup dengan doa; dan (12) memfasilitasi kemudahan dan keamanan ketika pengajian selesai sedang jamaah berkeinginan pulang ke rumahnya masingmasing.

Ketiga, bagi muballigh perlu memperhatikan berbagai tindakan agar pesan-pesannya yang disampaikan dalam pengajian umum benar-benar merasuk ke dalam jiwa para jamaah pengajian umum. Tindakan-tindakan tersebut meliputi antara lain: (1)menyampaikan pengajian umum penuh keihlasan dan konsentrasi pada materi yang disampaikan; (2)memilih kata-kata maupun kalimat-kalimat yang menumbuhkan suasana komunikatif; (3)menyambung kontak batin antara muballigh dengan jamaah;(4)memakai pakaian yang bagus sesuai dengan kondisi pengajian umum baik pakaian jubah, sarung berikut jas dan songkok, atau setidaknya celana berikut baju lengan panjang dan songkok; (5)menyampaikan pesanpesan pengajian secara sistematis; (6) menggunakan kata-kata, kalimat maupun bahasa yang mudah dipahami oleh jamaah pengajian; (7)menjelaskan pesan-pesan pengajian dengan menggunakan penalaran yang logis; (8)mengatur intonasi suara secara bergelombang (mengkombinasi intonasi suara antara yang rendah, sedang dan tinggi) sesuai dengan karakteristik pesan-pesan yang sedang disampaikan;(9) menghindari penggunaan kata-kata yang porno dan latah; (10) menekankan pemahaman dan penguasaan jamaah terhadap pesan-pesan yang disampaikan; (11) menyampaikan gurauan seperlunya 
saja (hindari terlalu banyak sikap bergurau hingga menggeser substansi isi pengajian itu sendiri); dan (12 )menjaga kewibawaan muballigh dengan menghindari kata-kata maupun tindakan yang merusak citranya seperti membicarakan amplop pengajian, oleh-oleh nasi dan kue, dan sebagainya. ${ }^{13}$

Menurut Abuddin Nata, kualitas muballigh perlu ditingkatkan karena peran dan fungsinya sekarang ini semakin berat, maka muballigh harus memainkan peranan: (1) para muballigh sebagai pengawal akhlak bangsa; (2) para muballigh sebagai penafsir jalan kehidupan umat manusia; (3) para muballigh sebagai informator dan penenang masyarakat; (4) para muballigh sebagai agen perubahan sosial (agent of social change), termasuk melakukan pembaruan pemikiran Islam; (5) para muballigh berperan dalam mengarahkan pandangan keislaman masyarakat; (6) para muballigh berperan dalam mewujudkan cita-cita Islam dalam berbagai bidang kehidupan; (7) para muballigh berperan dalam menanamkan keimanan dan ketaqwaan yang sesungguhnya; dan (8) para muballigh berperan sebagai pemimpin masyarakat. ${ }^{14}$

Di samping itu, muballigh dalam menyampaikan materi agama Islam di hadapan jamaah pengajian perlu menggunakan pendekatan tertentu yang disesuaikan baik dengan kondisi jamaah maupun kharakter pengajian umum tersebut, agar pelaksanaan pengajian mampu menghasilkan kualitas pemahaman, pengetahuan dan perubahan perilaku yang maksimal. M. Arifin menyarankan agar muballigh memegangi seperangkat pandangan yang didasarkan

13 Qomar, 93-99.

14 Abuddin Nata, Manajemen Pendidikan Mengatasi Kelemahan Pendidikan Islam di Indonesia (Jakarta: Kencana Prenada Media Group, 2012), 169-75. atas sistem pendekatan, antara lain: (1) pendekatan psikologis, (2) pendekatan sosial-kultural, (3) pendekatan religius, (4) pendekatan saintifik, (5) pendekatan pembangunan, dan (6)pendekatan security dan prosperity. ${ }^{15}$ Kombinasi dari berbagai pendekatan ini diharapkan benar-benar mampu melakukan transformasi kesadaran dan transformasi perilaku dari kesadaran dan perilaku yang masih lemah menjadi kesadaran dan perilaku yang makin kuat/ baik dalam menjalankan ajaran-ajaran Islam secara komprehensif.

Tantangan yang harus dihadapi oleh para Mubaligh terasa lebih berat lagi bagi mereka yang berada di kota-kota besar, atau pada tempat yang sudah masuk kedalam kemajuan zaman. Diberbagai Mass Media bahwa masyarakat sekarang dihadapkan dengan berbagai permasalahan berat, seperti adanya konflik sosial antara suku dan kelompok, tawuran antar pelajar, penjarahan, penodongan, penyerobotan tanah, pelecehan seksual, pembunuhan, penggunaan narkotik dan obat-obat berbahaya (narkoba), pelanggaran tata tertib lalu lintas, serta pelanggaran hak asasi manusia lainnya.Keadaan masyarakat yang demikian itu jelas menambah beban tugas para Mubaligh untuk ikut serta memberikan konstribusi untuk memecahkan masalah tersebut. Hal yang demikian perlu dilakukan, karena selain merusak kedudukan dan citra tempat, kota, daerah tersebut.

Sejalan dengan permasalahan tersebut, maka kehadiran para Mubaligh mutlak diperlukan. Dan, seiring dengan tantangan yang makin bert sebagaimana tersebut diatas, upaya meningkatkan kualitas para kader Mubaligh perlu dilakukan. Dengan melalui program peningkatan kader

$\overline{15}$ Arifin, Kapita selekta pendidikan, 122-23. 
Mubaligh, maka peran dan kontribusi mereka dalam memecahkan berbagai masalah tersebut akan lebih besar lagi. Demikian pula keberadaanmereka sebagai pengawal dan panutan serta tempat bertanya bagi masyarakat akan semakin meningkat.

Para Mubaligh perlu ditingkatkan kualitasnya, karena peran dan fungsi mereka pada masa sekarang ini semakin berat. Dalam kaitan ini paling kurang terdapat delapan hal penting yang harus dilakukan dna diperankan oleh Mubaligh sebagai berikut :

1. Para Mubaligh sebagai pengawal akhlak (moral) bangsa. Sejarah telah mencatat bahwa kelangsungan hidup suatu bangsa ditentukan oleh tinggi rendahnya akhlak (moral) bangsa yang bersangkutan. Dalam salah satu syairnya, Syauki Beiq mengatakan, sesungguhnya kelangsungan hidup suatu bangsa ditentukan oleh akhlak ( moralitasnya). Jika akhlak (moralitas) bangsa tersebut hancur, maka hancur pula bangsa tersebut. Dan dalam salah satu hadits Nabi Muhammad SAW. Yang diriwaytakan oleh Imam Ahmad, menerangkan tentang tingginya peran akhlak bagi orang yang beriman ( Iman dan budi pekerti) :

$$
\text { اكمل المؤهنين ايمانااحسنهم خلقا )روه احمد) }
$$

Artinya : " Orang Mukmin yang paling sempurna imannya ialah orang yang paling baik budi pekertinya" ( HR. Imam Ahmad)

Krisis moneter, ekonomi, politik, dan sebagainya yang melanda bangsa Indonesia saat ini serta berdampak buruk terhadap kehidupan masyarakat sebab utamanya adalah krisis akhlak. Indonesia saat ini ibarat habis dilanda gempa yang dahsyat. Disana- sini terdapat bangunan yang hancur, dinding yang retak, tiang yang miring dan bergeser, harta benda yang hancur sera korban jiwa yang bergelimpangan. Sesuai keterangan dari firman Allah. SWT yang artinya : "Telah nampak kerusakan di darat dan di laut disebabkan karena perbuatan tangan manusi, supay Allah merasakan kepada mereka sebahagian dari (akibat) perbuatan mereka, agar mereka kembali (ke jalan yang benar)."( QS. Ar- Rum : 41)

2. Para Mubaligh sebagai penafsir jalan kehidupan umat manusia. Ini artinya, para Mubaligh pada dasarnya adalah pekerja- pekerja budaya yang selalu berupaya agar suatu kebudayaan berkembang mencapai bentuknya yang lebih beradab, sesuai dengan tuntutan zaman.

3. Para Mubaligh sebagai informator dan penerang masyarakat. Masyarakat amat haus terhadap informasi, petunjuk dan penerangan dari para Mubaligh. Informasi, petunjuk, dan penerangan yang disampaikan oleh Mubaligh akan lebih diterima oleh masyarakat daripada informasi, petunjuk, penerangan yang disampaikan oleh pihak lain. Namun demikian agar informasi, petunjuk dan penerangan yang disampaikan itu tidak menyesatkan masyarakat, maka para mubaligh harus melengkapi dirinya dengan data yang akurat dan dapat dipercaya. Data dan informasi tersebut biasanya terdapat pada saluran teknologi informasi seperti Internet baik dalam jejaring sosial maupun global sosial, dan berbagai mass media lainnya. Untuk itu para mubaligh juga harus mampu menggunakan berbagai peralatan teknologi informasi tersebut, sehingga mampu mengakses berbagai informasi dari seluruh penjuru dunia. 
4. Para Mubaligh sebagai agen perubahan sosial ( agent of social change) yang ada di dalamnya termasuk melakukan pembaruan pemikiran Islam. Muncul Keinginan untuk melakukan pembaruan terhadap ajaran Islam dalam bidang Fiqih dan teologi, misalnya didasari oleh pertimbangan yang bersifat internal dan eksternal. Hal pertama yang menjadi bahan pertimbangan adalah karena karena Fiqih dan Teologi dalam Islam terjebak dalam status quo. Sementara itu, pada sisi yang lain, sebagai pertimbangan eksternal, permasalahanpermasalahan aktual yang terus bergulir yang membutuhkan pertimbangan moral dan etik yang bertitik tolak dari kerangka pandangan keagamaan.

5. Para Mubaligh berperan dalam mengarahkan pandangan keislaman masyarakat. Dewasa ini banyak corak pemikiran paham keislaman di Indonesia, seperti Islam Fundamental, Islam Teologis- Formatif, Islam Ekslusif, Islam Rasional, Islam Transformatif, Islam Aktual, Islam Modernis, Islam Kultural, serta Islam Inklusif- Pluralis. Berbagai corak pemikiran Islam tersebut telah ditulis oleh para cendikiawan Muslim Indonesia, seperti Mukti Ali, Munawir Sadzali, Harun Nasution, Muhamad Natsir, dan lainnya, yang mana mereka sudah menulis sejumlah buku untuk menjelaskan berbagai corak pemikiran Islam tersebut.

6. Para Mubaligh berperan dalam mewujudkan cita- cita Islam dalam berbagai bidang kehidupan. Dalam bidang sosial, Islam mencita- citakan suatu masyarakat yang egaliter, yaitu masyarakat yang didasarkan pada prinsip kesetaraan dan kesederajatan. Atas dasar ini kedudukan dan kehormatan manusia di hadapan Allah. SWT. Dan di hadapan manusia lainnya bukan didasarkan pada perbedaan suku bangsa, golongan, bahasa, warna kulit, pangkat, keturunan, harta benda, tempat tinggal, dan lain sebagainya, melainkan didasarkan atas ketakwaan dan darmabaktinya kepada masyarakat. Sesuai firman Allah. SWT yang artinya: "Hai manusia, Sesungguhnya Kami menciptakan kamu dari seorang lakilaki dan seorang perempuan dan menjadikan kamu berbangsa - bangsa dan bersuku-suku supaya kamu saling kenal-mengenal. Sesungguhnya orang yang paling mulia diantara kamu disisi Allah ialah orang yang paling taqwa diantara kamu. Sesungguhnya Allah Maha mengetahui lagi Maha Mengenal..'( QS. Al- Hujurat : 13)

Dalam bidang politik, Islam mencitacitakan suatu pemerintahan yang dipimpin oleh orang yang adil, jujur, amanah, demokratis, dan kredibel, sesuai firman Allah. SWT. yang artinya: "Sesungguhnya Allah menyuruh (kamu) Berlaku adil dan berbuat kebajikan, memberi kepada kaum kerabat, dan Allah melarang dari perbuatan keji, kemungkaran dan permusuhan. Dia memberi pengajaran kepadamu agar kamu dapat mengambil pelajaran". ( QS. An- Nahl : 90)

Selanjutnya, dalam bidang ekonomi, Islam mencita- citakan keadaan ekonomi yang didasarkan pada pemerataan, anti-monopoli, saling menguntungkan, tidak saling merugikan, seperti menipu, mencuri, dan sebagainya. Sesuai Firman Allah. SWT yang artinya: "Hai orangorang yang beriman, janganlah kamu melanggar syi'ar-syi'ar Allah, dan jangan melanggar kehormatan bulan-bulan 
haram, jangan (mengganggu) binatangbinatang had-ya, dan binatang-binatang qalaa-id, dan jangan (pula) mengganggu orang-orang yang mengunjungi Baitullah sedang mereka mencari kurnia dan keredhaan dari Tuhannya dan apabila kamu telah menyelesaikan ibadah haji, Maka bolehlah berburu. dan janganlah sekali-kali kebencian(mu) kepada sesuatu kaum karena mereka menghalang-halangi kamu dari Masjidilharam, mendorongmu berbuat aniaya (kepada mereka). dan tolongmenolonglah kamu dalam (mengerjakan) kebajikan dan takwa, dan jangan tolong-menolong dalam berbuat dosa dan pelanggaran. dan bertakwalah kamu kepada Allah, Sesungguhnya Allah Amat berat siksa-Nya". (Q.S. Al- Maidah : 2)

Sementara itu, dalam bidang hukum Islam mencita- citakan tegaknya supremasi hukum yang didasarkan pada keadilan, tidak pilih kasih (Diskriminatif), manusiawi, konsisten, dan objektif dalam kerangka melindungi seluruh aspek hak asasi manusia yang meliputi hak untuk hidup, hak untuk beragama, hak untuk memiliki dan memanfaatkan harta, hak untuk memiliki dan mengembangkan keturunan, serta hak untuk mendapatkan pendidikan dan mengembangkan intelektualitasnya. $\mathrm{Al}$-syathibi, Al- Muwafaqat fi Ushul AlAhkam. Cita- cita Islam yang demikian ideal itu harus diperjuangkan secara sungguh- sungguh dan konsisten oleh para Mubaligh. Cita- cita tersebut bukan dimaksudkan untuk mendirikan negara Islam, melainkan semata mata untuk mewujudkan rahmat dan kedamaian di muka bumi, sebagaimana hal yang demikian itu, menjadi tujuan diturunkannya agama Islam ke muka Bumi.

7. Para Mubaligh berperan dalam menanmkan keimanan dan ketakwaan dalam arti yang sesungguhnya. Yaitu, keyakinan akan adanya Allah. SWT. Sebagai Tuhan yang wajib disembah yang diikuti dengan kesadaran untuk melaksanakan perintah- Nya dan menjauhi segala larangan- Nya. Keimanan dan ketakwaan yang demikian itu, benar-benar tertanam dalam hati dan terimplementsikan dalam prilaku kehidupan sehari- hari. Keimanan dalam hati diupayakan berperan seperti polisi rahasia, yang selalu mengawasi gerakgerik perbuatan manusia. Dengan cara demikian ia selalu merasa diawasi oleh Allah. SWT. Dan pada akhirnya ia tidak berani melakukan perbuatan yang dilarang oleh Allah. SWT. Dan Rasulullah SAW.

8. Para Mubaligh berperan sebagai pemimpin masyarakat. Dengan memperhatikan delapan peran yang harus dilakukan para Mubaligh tersebut, maka perlu ditingkatkan kualitasnya. Hal ini penting dilakukan mengingat peran yang harus dimainkan para Mubaligh semakin hari semakin berat, rumit, serta penuh tantangan dan rintangan.

Dilihat dari segi caranya, strategi pembinaan kualitas Mubaligh dapat dilakukan melalui dua jalur.

1. Jalur pendidikan formal. Mereka harus diberi kesempatan untuk meningkatkan pendidikannya pada pPerguruan Tinggi yang secara khusus mencetak para Mubaligh secara profesional. Melalui jenjang pendidikan ini mereka selain bisa berperan sebagai praktisi Mubaligh tetapi juga sebagai perancang, konseptor, 
pengamat, dan evakuator dalam bidang dakwah yang semakin maju dan berkembang.

2. Melalui jalur Pelatihan (pendidikan non formal) yang terprogram sebagaimana dilakukan oleh LPKPU MUI Kabupaten Bogor. Hal ini penting dilakukan, karena selain terarah kepada tugasnya sebagai mubaligh juga waktunya relatif singkat. Jalur pelatihan ini selain harus didukung oleh tenaga pelatih (pendidik) yang handal, berpengalaman dan penuh dedikasi, juga harus pula didukung oleh sarana dan prasarana yang modern, dan lengkap seperti laboratorium, komputer, perpustakaan, dan sebagainya. Dengan cara demikian mereka akan menjadi tenaga- tenaga Mubaligh yang benarbenar profesional.

Selanjutnya, dilihat dari segi materinya, pelatihan tenaga Mubaligh harus diisi dengan materi- materi yang benar- benar dibutuhkan dalam melaksanakan tugasnya sebagai Mubaligh seperti pengetahuan tentang permasalahan sosial, retorika, dan lain sebagainya. Dengan cara demikian mereka akan memiliki bekal yang cukup dalam mengelola bahan tabligh- nyadengan tepat guna. Selain itu, dilihat dari segi fungsi dan perannya, pelatihan (pendidikan nonformal) Mubaligh harus bisa menyadarkan kepada para kader Mubaligh tentang fungsinya yang amat strategis, dalam rangka pembinaan umat. Dengan menyadari fungsinya, maka para Mubaligh akan melaksanakan tugasnya sebagai panggilan moral, ruhul jihad, dan bukan karena mengharapkan keuntungan sesaat.

\section{Penutup}

Dari pembahasan tersebut, maka penulis dapat mengambil kesimpulan sebagai berikut:

1. Majlis taklim merupakan perkumpulan pengajian, sehingga motifnya adalah mencari ilmu agama dan mendapatkan pahala dari Allah, sehingga pesertanya semakin berkembang pesat di berbagai daerah, khususnya kalangan ibu-ibu rumah tangga yang merasakan haus siraman rohani.

2. Supaya berlangsung efektif dan efisien, maka majlis taklim perlu dikelola dengan baik dengan ditata kurikulumnya sampai pada pembinaan juga rolling ustadz yang memberikan materi.

3. Pengajian umum adalah pengajian ilmu agama yang sifatnya ditampilkan untuk umum dan semua khalayak.

4. Pengajian umum mendapatkan berbagai tantangan dan untuk menghadapi tantangan tersebut maka pengajian umum perlu langkah-langkah strategis.

\section{DAFTAR RUJUKAN}

Arifin, H. Muzayyin. Kapita Selekta Pendidikan (Islam dan Umum). Jakarta: Bumi Aksara, 1991.

Daradjat, Zakiah. Metodik Khusus Pengajaran Agama Islam. Jakarta: Bulan Bintang, 1980.

Marzali, Amri. Pemberdayaan Majlis Taklim Melalui Pendekatan Sosiologi", dalam Kustini (ed.), Hasil Seminar Peningkatan Peran Serta Masyarakat dalam Pendalaman Ajaran Agama Melalui Majlis Taklim,. Jakarta: Badan Litbang dan Diklat Puslitbang Kehidupan 
44 |

Keagamaan Departemen Agama RI, 2007.

Muhayat. Manajemen dan Silabus Majelis Taklim. Jakarta: Pusat Pengkajian dan Pengembangan Islam Jakarta, 2012.

Nata, Abuddin. Manajemen Pendidikan Mengatasi Kelemahan Pendidikan Islam di Indonesia. Jakarta: Kencana Prenada Media Group, 2012.

Qomar, Mujamil. Dimensi Manajemen Pendidikan Islam. Jakarta: Erlangga, 2015.

RI, UU. “No. 20 Tahun 2003.” Tentang Sistem Pendidikan Nasional, 2003. 